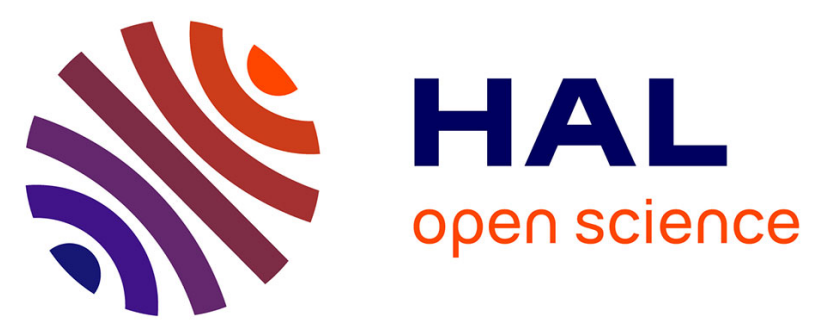

\title{
State of the Sub-surface Microstructure of Carbides strengthened cast Superalloys after High Temperature Oxidation -Use of Thermodynamic Modelling for a better Understanding
}

P. Berthod, S Michon, S Mathieu, Renaud Podor, C Rapin, P Steinmetz

\section{To cite this version:}

P. Berthod, S Michon, S Mathieu, Renaud Podor, C Rapin, et al.. State of the Sub-surface Microstructure of Carbides strengthened cast Superalloys after High Temperature Oxidation -Use of Thermodynamic Modelling for a better Understanding. Materials Science Forum, 2004, 461-464, pp.1117 - 1124. 10.4028/www.scientific.net/MSF.461-464.1117 . hal-02275486

\author{
HAL Id: hal-02275486 \\ https://hal.science/hal-02275486
}

Submitted on 30 Aug 2019

HAL is a multi-disciplinary open access archive for the deposit and dissemination of scientific research documents, whether they are published or not. The documents may come from teaching and research institutions in France or abroad, or from public or private research centers.
L'archive ouverte pluridisciplinaire HAL, est destinée au dépôt et à la diffusion de documents scientifiques de niveau recherche, publiés ou non, émanant des établissements d'enseignement et de recherche français ou étrangers, des laboratoires publics ou privés. 


\title{
State of the Sub-surface Microstructure of Carbides strengthened cast Superalloys after High Temperature Oxidation - Use of Thermodynamic Modelling for a better Understanding
}

\author{
P. Berthod, S. Michon, S. Mathieu, R. Podor, C. Rapin and P. Steinmetz \\ Laboratoire de Chimie du Solide Minéral (UMR 7555), Faculté des Sciences et Techniques, \\ Université Henri Poincaré Nancy 1, BP 239, 54506 Vandoeuvre-Les-Nancy Cedex, France \\ patrice.berthod@centraliens-lille.org
}

Post-print version of the article: Materials Science Forum (2004) Vols. 461-464, pp.1117-1124

Keywords: High Temperature Oxidation, Thermodynamic Modelling, Cast Superalloys, Carbides

\begin{abstract}
Several cast strengthened superalloys, Ni base and Co base, were exposed to high temperature oxidation for long times and metallographically examined. Different phenomena occurred in the sub-surface microstructure, depending on both alloy and temperature. Thermodynamic modelling was used to know what it happened for carbon during oxidation, then to explain the observed microstructural changes. It appears that carbon atoms either quit the alloy probably after its oxidation into gases, or on the contrary go deeper into the bulk where they promote the precipitation of new carbides by solid state transformation. Thereafter, thermodynamic modelling allowed to know the new local refractoriness of the zones affected by oxidation, then to appreciate the new mechanical properties in the sub-surface.
\end{abstract}

\section{Introduction}

When exposed to high temperature oxidation most of superalloys become covered by alumina or chromia oxide scales. They are often affected by internal oxidation too, in the matrix or in grain boundaries [1]. But other phenomena can also occur, such as microstructural modifications in the neighbourhood of the oxidation front. For carbides strengthened superalloys after high temperature oxidation, it is often seen that there is an external zone, all along the alloy surface, in which microstructure has been damaged (Fig. 1). For example, this sub-surface microstructure can encounter a disappearance of secondary carbides, a lost of the intergranular carbides with formation of holes or not, precipitation of new phases, ... These modifications of the sub-surface microstructural state are not always easy to understand, notably since some elements, like carbon, cannot be analysed because of their too light atomic weight and too small weight content in the bulk. Thermodynamic modelling can be in such cases of a good help. First, when applied in an inverted sense with regard to how it is usually used, one can think that it allows to know the local content of carbon, and then what happened for this element during oxidation. Second, knowing the whole chemical composition, it leads to appreciate the consequences, on the local refractoriness, of the microstructural and chemical changes due to oxidation.

\section{Experimental}

Synthesis of the studied alloys. The alloys studied here are of two types. In order to begin this study with a simple example, a ternary Ni-Cr-C nickel alloy was first synthesised. 


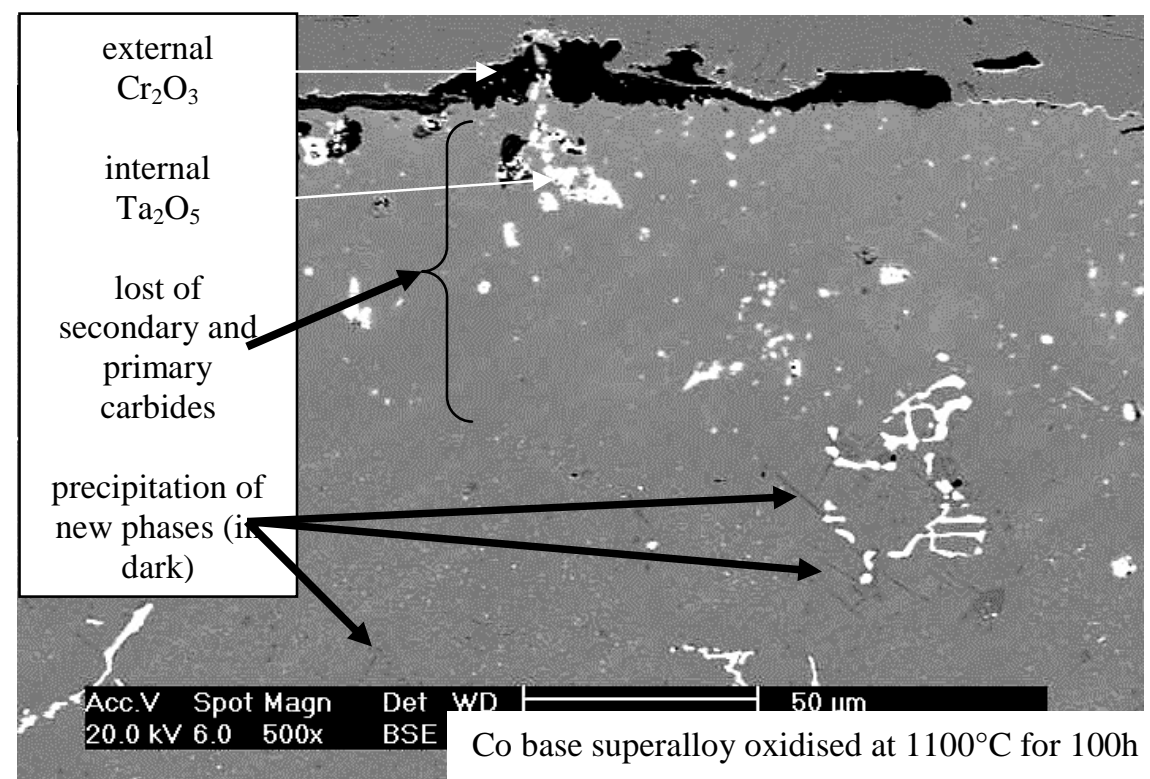

Fig. 1: Example of deterioration of the sub-surface microstructure by oxidation

Working on such an alloy simplifies the problem by allowing first to analyse in the best conditions the local chemical compositions (except carbon) without any interaction between two elements, and second to perform thermodynamic calculations using a well known database. It was prepared in small quantity (ingots of nearly $50 \mathrm{~g}$ ) by high frequency induction melting under argon gas in a copper cold crucible in which it also solidified. Its microstructure is constituted of a nickel austenitic matrix (including a part of the $\mathrm{Cr}$ and $\mathrm{C}$ atoms in solid solution) and of chromium carbides at grain boundaries.

Second, two cobalt base superalloys were obtained using another induction furnace (capacity of several kg) under argon gas too. The molten alloys were poured and solidified in a sand mould. Thereafter these two cobalt base superalloys underwent a homogenisation treatment at $1200^{\circ} \mathrm{C}$ for 2 hours, followed by a precipitation stage at $1000^{\circ} \mathrm{C}$ for 10 hours, in order to get a precipitation of thin carbides in matrix. These Co base superalloys contain mainly cobalt, nickel and chromium but also tantalum and carbon, the latter elements promoting the formation of refractory $\mathrm{Cr}_{23} \mathrm{C}_{6}$ and/or $\mathrm{TaC}$ carbides which are known to be of a great importance for mechanical properties at high temperature $[2,3]$.

\begin{tabular}{|c|c|c|c|c|c|}
\hline Alloys & Co & Ni & Cr & C & Ta \\
\hline Alloy1 & $/$ & bal & 30 & 0.2 & $/$ \\
\hline Alloy2 & bal & 8.5 & 30 & 0.4 & 6 \\
\hline Alloy3 & bal & 8.5 & 30 & 1.0 & 6 \\
\hline
\end{tabular}

Table 1: Typical chemical compositions of the studied alloys (in weight \%)

High temperature oxidation runs and microstructure examinations. Oxidation tests were performed at $1000^{\circ} \mathrm{C}, 1100^{\circ} \mathrm{C}$ and $1200^{\circ} \mathrm{C}$ for 100 hours, using a Setaram thermobalance under a flow of industrial air $\left(80 \% \mathrm{~N}_{2}-20 \% \mathrm{O}_{2}\right)$ of about $1,5 \mathrm{~L} / \mathrm{min}$. Samples were parallelepipeds, the dimensions of which were approximately $10 \mathrm{~mm} \times 10 \mathrm{~mm}$ x $2 \mathrm{~mm}$. After tests, oxidised samples were covered with a gold layer by cathodic plasma pulverisation which allowed the external surface 
to become electrically conductive. Then a sufficiently thick electrolytic nickel coating was deposited in order to protect the external chromia layer before cutting. Thereafter samples were cut, embedded in epoxy resin and polished up to 1200 grid paper. A Scanning Electron Microscope (SEM) Philips XL30 was used in Back Scattered Electrons (BSE) mode for the surface and bulk examinations. The constitutive phases can be clearly evidenced since their average atomic numbers are sensibly different. In addition, some of them were identified by Energy Dispersion Spectrometry (EDS), or by Wavelength Dispersion Spectrometry (WDS) using a Cameca SX100 microprobe. EDS enabled also to analyse the mean chemical composition of a selected area over the local microstructure while microprobe was also used to get concentration profiles through the external zone damaged by oxidation.

Image analysis and thermodynamic calculations. Surface fractions of the different phases were estimated on SEM photographs (BSE mode), using the AnalySIS software of Soft Imaging System GMBH. Making the hypothesis that surface fraction and volume fraction have similar values, volume fractions were assessed. Using the equation (Eq. 1) with room temperature densities of the different phases, it was possible to estimate the mass fraction of each phase. The values used for the specific weights (in g.cm ${ }^{-3}$ ) were 8.90 for the matrix, 6.94 for the $\mathrm{Cr}_{7} \mathrm{C}_{3}$ carbide, 6.95 for the $\mathrm{Cr}_{23} \mathrm{C}_{6}$ carbide and 14.50 for the TaC carbide [4].

$$
\mathrm{f}_{\text {mass }}\left(\varphi_{\mathrm{j}}\right)=\frac{\rho_{\varphi_{\mathrm{j}}} \cdot \mathrm{f}_{\mathrm{vol}}\left(\varphi_{\mathrm{j}}\right)}{\sum_{\mathrm{i}}\left(\rho_{\varphi_{\mathrm{i}}} \cdot \mathrm{f}_{\mathrm{vol}}\left(\varphi_{\mathrm{i}}\right)\right)}
$$

Calculations on the simple nickel alloy were carried out using Windows version Thermo-Cal software with the SSOL database (SGTE). For the cobalt alloys, N Thermo-Calc software was used in association with a new database. This last one is the SSOL database completed with binary and ternary systems involving the Ta element. It had been already used to study analogous alloys in other studies $[5,6,7]$.

\section{Results obtained on the simple nickel alloy (Alloy1)}

Surface microstructure after oxidation at $1000^{\circ} \mathrm{C}$ and $1100^{\circ} \mathrm{C}$ for 100 hours. At $1000^{\circ} \mathrm{C}$, the initial sub-surface microstructure of Alloy1 is transformed into two separated zones (Fig. 2). The outer one, thereafter called "carbideless zone", has completely lost its carbides. The inner zone still contains some carbides but with a rounder shape. One also can see a population of new phases with an acicular shape, different sizes and precise orientations. Spot microanalysis showed that both acicular particles and compact particles are $\mathrm{Cr}_{7} \mathrm{C}_{3}$ carbides. WDS chromium profiles, were compared to the different microstructural zones. The carbideless zone corresponds to a high $\mathrm{Cr}$ gradient and a chromium range of [21\%wt , 26\%wt] while the zone containing acicular carbides exhibits a lower $\mathrm{Cr}$ gradient and higher $\mathrm{Cr}$ contents. SEM photographs were taken on several areas (of about $80 \mu \mathrm{m} \times 120 \mu \mathrm{m}$ ) in the acicular precipitation zone, on which image analysis were performed. EDS analysis of the chemical composition was realised on the same areas. The six results lead to an average of $4.6 \%$ mass of $\mathrm{Cr}_{7} \mathrm{C}_{3}$ carbides (mass fraction) in the microstructure and to a $\mathrm{Cr}$ content of $29.8 \%$ wt $\mathrm{Cr}$.

At $1100^{\circ} \mathrm{C}$, the damaged zone of Alloy1 seems to be only composed of the carbideless zone, which is three times deeper than the one resulting from oxidation at $1000^{\circ} \mathrm{C}$. From the bulk, the WDS $\mathrm{Cr}$ content profile shows that chromium content decreases from $31 \%$ wt $\mathrm{Cr}$ to about $25 \% \mathrm{wt} \mathrm{Cr}$.

Thermodynamic calculations. An isothermal ternary $\mathrm{Ni}-\mathrm{Cr}-\mathrm{C}$ diagram was computed for $\mathrm{T}=1000^{\circ} \mathrm{C}$ (Fig. 3). Considering the nickel-rich corner and the $\mathrm{Cr}$ contents measured with WDS 

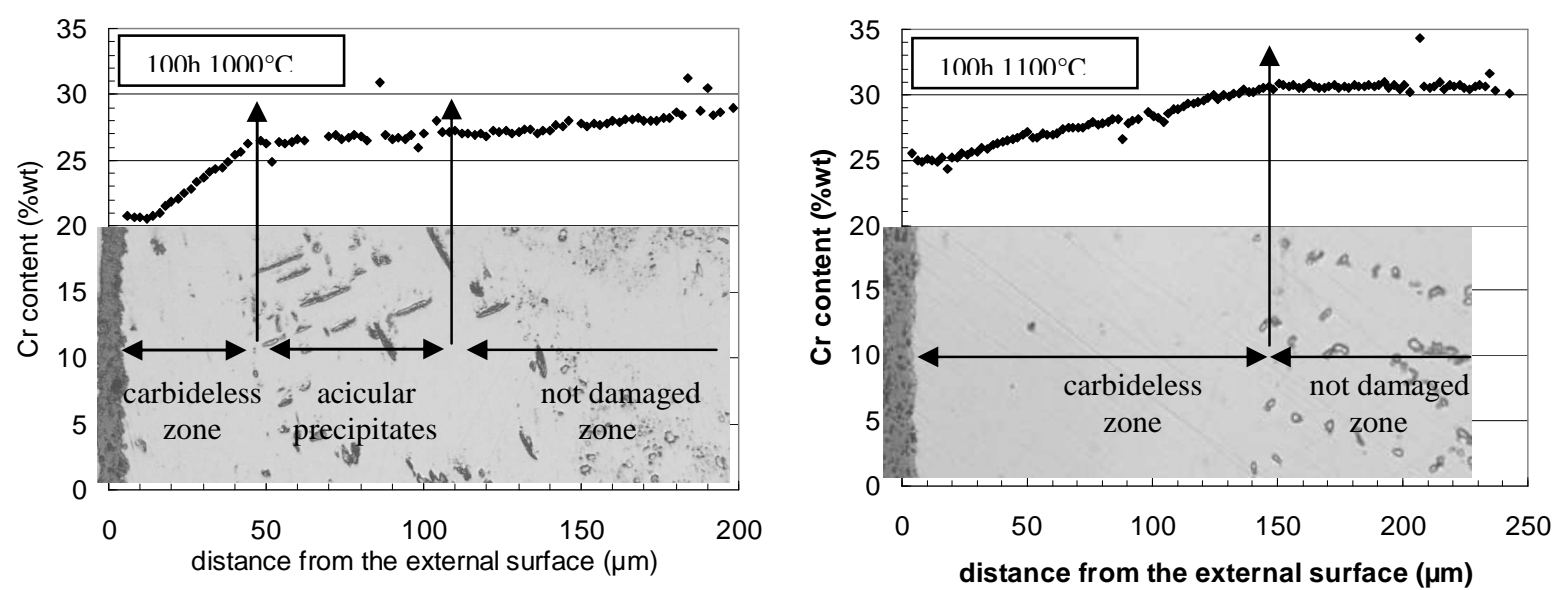

Fig. 2: Sub-surface microstructural changes for Alloy1 and correspondence between the different zones and the Cr profile

profiles over this zone, a range of possible values for \%wt $\mathrm{C}$ was assessed. For each limit of chromium (21 and 26\%wt Cr), Thermo-Calc Windows gave the two upper limits for the carbon content allowing the existence of the matrix alone. Thus, the carbideless zone must contain less than $0.037 \%$ wt $\mathrm{C}$ close to the surface and less than $0.019 \%$ wt $\mathrm{C}$ on the frontier <carbideless zone acicular carbides zone>. Secondly, for each microphotograph obtained on the zone with acicular carbides, Thermo-Calc Windows calculations were performed, taking into account the chromium content measured by EDS. Successive values of the carbon content were tested until the mass fraction of the $\mathrm{Cr}_{7} \mathrm{C}_{3}$ carbides reached the experimental value given by image analysis (without appearance of any new phases different than matrix and $\mathrm{Cr}_{7} \mathrm{C}_{3}$ of course). On the six carbon contents which were obtained on the six studied areas (all contained between 0.40 and $0.55 \%$ wt $\mathrm{C}$ ), the average value was $0.435 \%$ wt $\mathrm{C}$.

Then, the initial microstructure near the surface, which contained the same chromium and carbon contents (30\%wt $\mathrm{Cr}, 0.20 \%$ wt $\mathrm{C}$ ) and the same phases (matrix, primary Cr carbides) as the bulk before oxidation test, has evolved because of the oxidation phenomena. It has been replaced by two distinct zones : a carbideless zone strongly impoverished in carbon (21 to 26\%wt $\mathrm{Cr}$ and less than 0.04 to $0.02 \%$ wt $\mathrm{C}$ ) and another zone containing new acicular carbides and a higher carbon content (over the double of the initial content). These two zones have almost the same depth of about $50 \mu \mathrm{m}$.

THERMO-CALC (2003.06.24:15.18) :

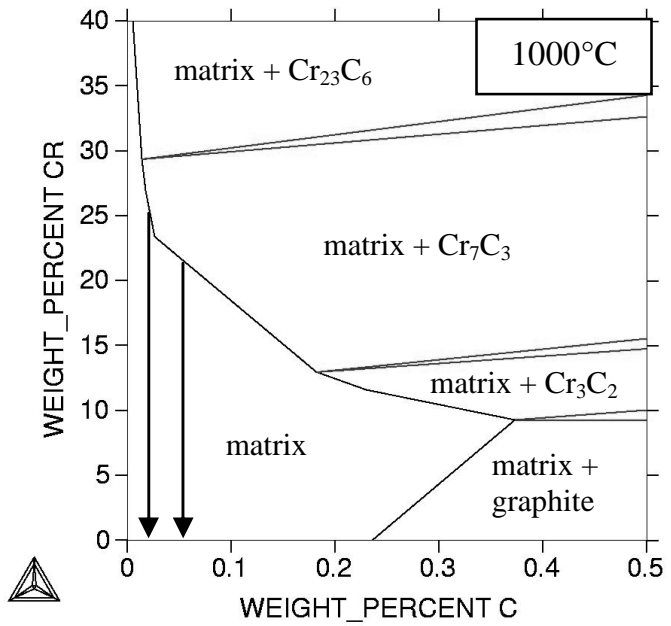

THERMO-CALC (2003.06.25:18.33) :

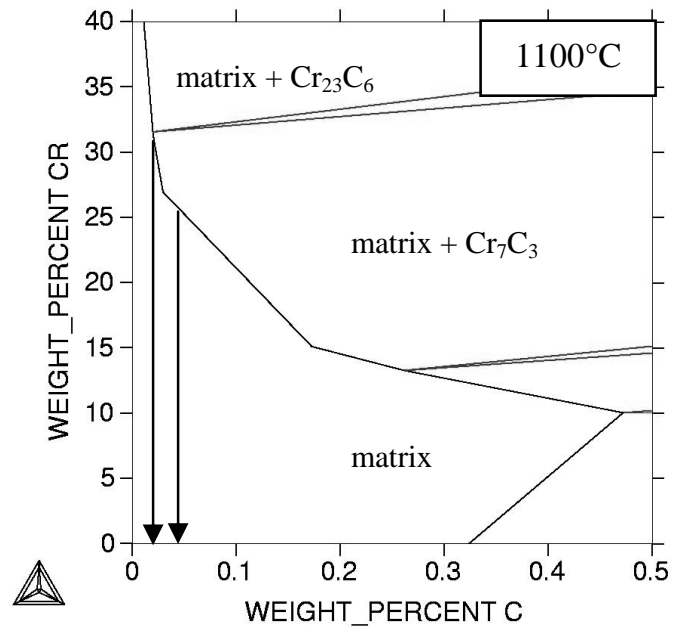

Fig. 3: Isothermal ternary $\mathrm{Ni}-\mathrm{Cr}-\mathrm{C}$ diagrams for $\mathrm{T}=1000^{\circ} \mathrm{C}$ and for $\mathrm{T}=1100^{\circ} \mathrm{C}$ (in the Ni-rich corner) 
On the isothermal diagram obtained for $1100^{\circ} \mathrm{C}$, the absence of any other phases than matrix indicates that the carbon content must be lower than $0.054 \%$ wt $\mathrm{C}$ at the extreme surface (where $\% \mathrm{wtCr}=25$ ) and lower than $0.025 \%$ wt $\mathrm{C}$ at the junction of the carbideless zone and the bulk (where $\%$ wtCr=31). In this way, this zone of the alloy has lost a great part of its initial carbon content. Everywhere else in the alloy, the carbide surface fraction seems to be the same as in the bulk, then there is no region that became enriched with a part of carbon lost by the damaged zone.

\section{Results obtained on the two cobalt base superalloys (Alloy2 and Alloy3)}

Surface microstructure after oxidation at $1000^{\circ} \mathrm{C}$ and $1200^{\circ} \mathrm{C}$ for 100 hours. Initial bulk microstructure is composed first of an austenitic cobalt matrix with other elements in solid solution. In the interdendritic spaces of Alloy2 there are tantalum carbides belonging to an eutectic with the matrix, whereas Alloy3 contains both eutectic TaC carbides and eutectic $\mathrm{Cr}_{7} \mathrm{C}_{3}$ in grain boundaries. These carbides strengthen these superalloys which are very resistant mechanically at high temperature. Apart the external $\left(\mathrm{Cr}_{2} \mathrm{O}_{3}\right)$ and internal $\left(\mathrm{Ta}_{2} \mathrm{O}_{5}\right.$ or $\left.\mathrm{CrTaO}_{4}\right)$ oxides, new acicular oriented phases appeared in the alloys not far from the oxidation front. They are visible in a zone separating a thin carbideless zone and the not damaged zone (Fig. 4).

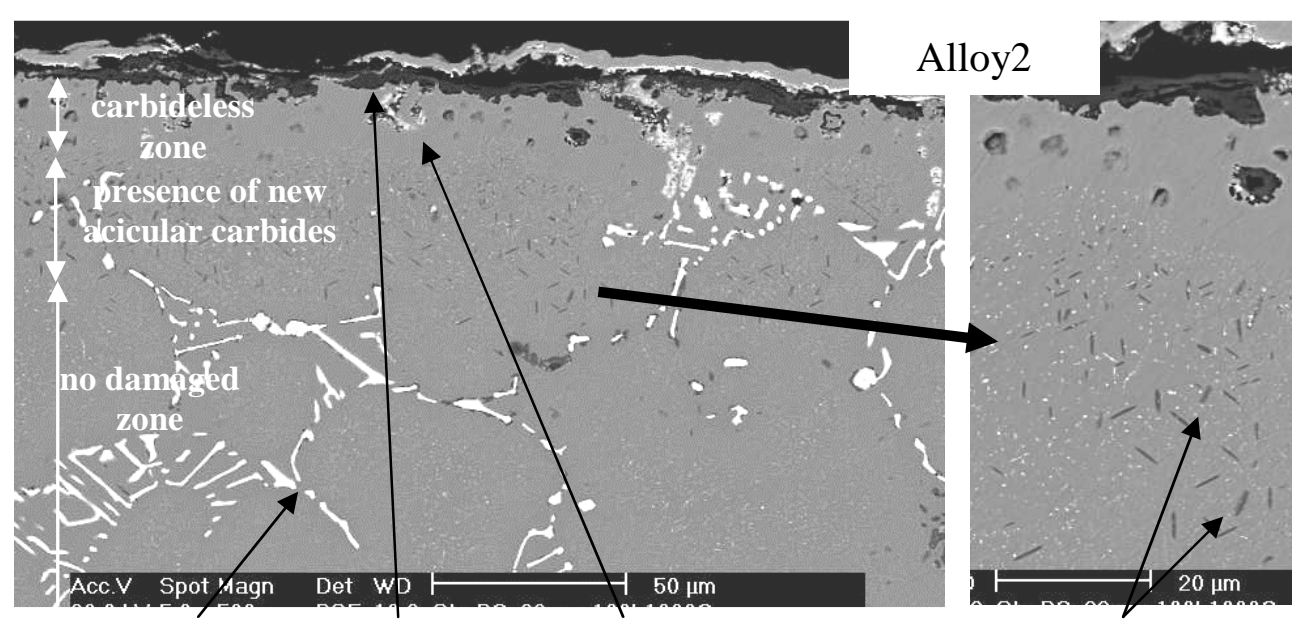

$\mathrm{Cr}_{7} \mathrm{C}_{3} \quad \mathrm{TaC} \quad$ external $\mathrm{Cr}_{2} \mathrm{O}_{3}$ internal $\mathrm{Ta}_{2} \mathrm{O}_{5}$

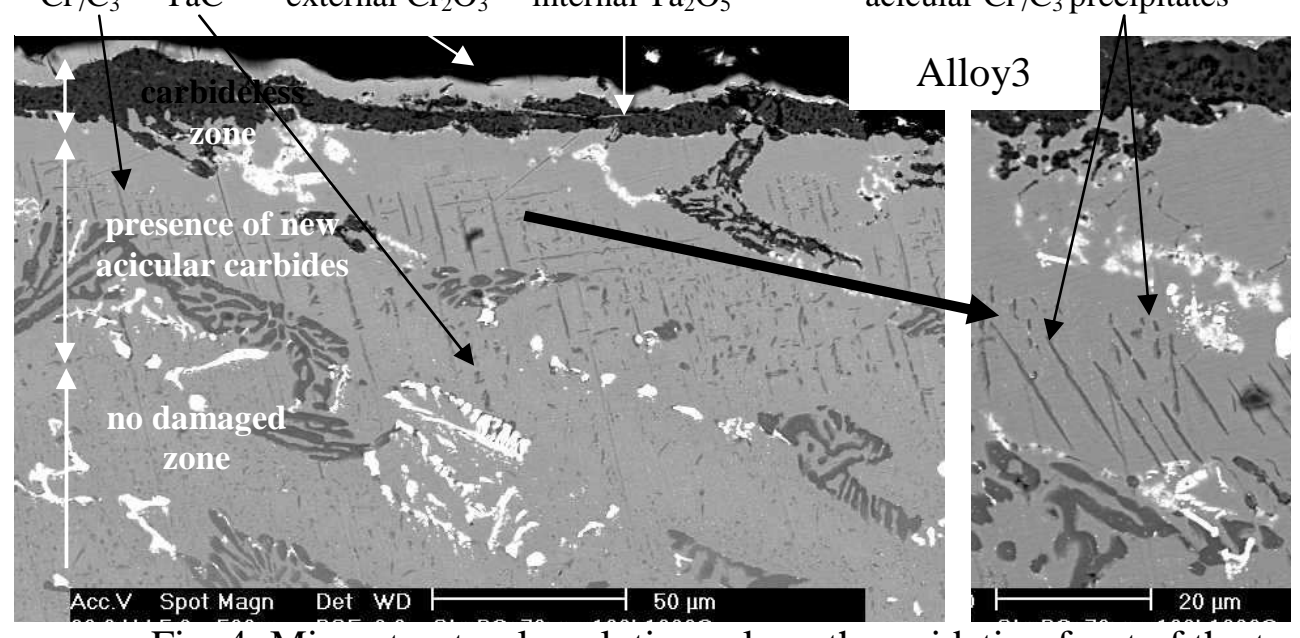

Fig. 4: Microstructural evolutions along the oxidation front of the two cobalt base alloys after oxidation at $1000^{\circ} \mathrm{C}$ for $100 \mathrm{~h}$

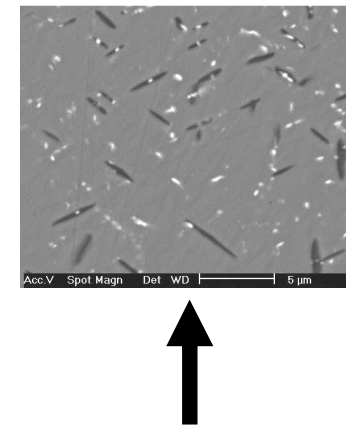

examples of zones on which surface fractions were measured

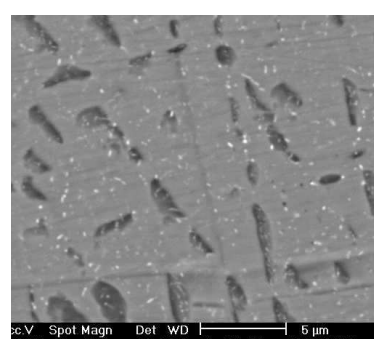

\section{年}


zone, which is of about $15 \mu \mathrm{m}$ for Alloy 2 and of $10 \mu \mathrm{m}$ for Alloy3. EDS profiles were performed through the carbideless zone. They showed for Alloy2 that the chromium and tantalum contents decrease respectively from $20 \% \mathrm{wt} \mathrm{Cr}$ to $16 \% \mathrm{wt} \mathrm{Cr}$ and from $1.0 \% \mathrm{wt}$ Ta to $0.0 \% \mathrm{wt}$ Ta between the frontier of the zone which still contains carbides and the extreme surface. For Alloy3, these contents decrease from $21 \%$ wt $\mathrm{Cr}$ to $18 \%$ wt $\mathrm{Cr}$ and from $1.6 \%$ wt Ta to $1 \%$ wt $\mathrm{Ta}$.

Several high magnification SEM photographs were taken on delimited areas of about $500 \mu \mathrm{m}^{2}$ in the acicular precipitation zone (Fig. 4 right) to be thereafter subjects to image analysis measurements. On the same areas global chemical compositions were analysed by EDS. For each alloy three results were obtained and they showed similar values. On these areas Alloy 2 contains $3.3 \%$ surf $\mathrm{Cr}_{7} \mathrm{C}_{3}$ and $1.0 \%$ surf $\mathrm{TaC}$ (surface fractions), then $2.6 \%$ mass of $\mathrm{Cr}_{7} \mathrm{C}_{3}$ and $1.6 \%$ mass of $\mathrm{TaC}$ (mass fractions), for a local chemical composition of $27.7 \mathrm{Cr}-9.8 \mathrm{Ni}-2.1 \mathrm{Ta}$ (bal. $\mathrm{Co}$ ) in weight percent. Alloy3 contains $10.1 \%$ surf $\mathrm{Cr}_{7} \mathrm{C}_{3}$ and $0.7 \%$ surf $\mathrm{TaC}$, then $8.0 \%$ mass of $\mathrm{Cr}_{7} \mathrm{C}_{3}$ and $1.2 \%$ mass of $\mathrm{TaC}$, for a local chemical composition measured of $28.9 \mathrm{Cr}-9.4 \mathrm{Ni}-1.6 \mathrm{Ta}$ (bal Co).

Alloy3 was also exposed to oxidation at $1200^{\circ} \mathrm{C}$ for 100 hours. Apart an external chromia layer three times thicker and an internal oxidation of Ta more developed than for $1000^{\circ} \mathrm{C}$, it exhibits a deeper carbideless zone (Fig. 5). Like for Alloy1 at $1100^{\circ} \mathrm{C}$, no precipitation of new phases is visible. Here too EDS spot analysis were performed across the carbideless zone. From the frontier of the not damaged zone towards the extreme surface, $\mathrm{Cr}$ and Ta contents decrease from $22 \%$ wt $\mathrm{Cr}$ and $1.5 \%$ wt Ta to $17 \%$ wt $\mathrm{Cr}$ and $0.3 \%$ wt Ta, the nickel content staying at about $10 \%$ wt $\mathrm{Ni}$.

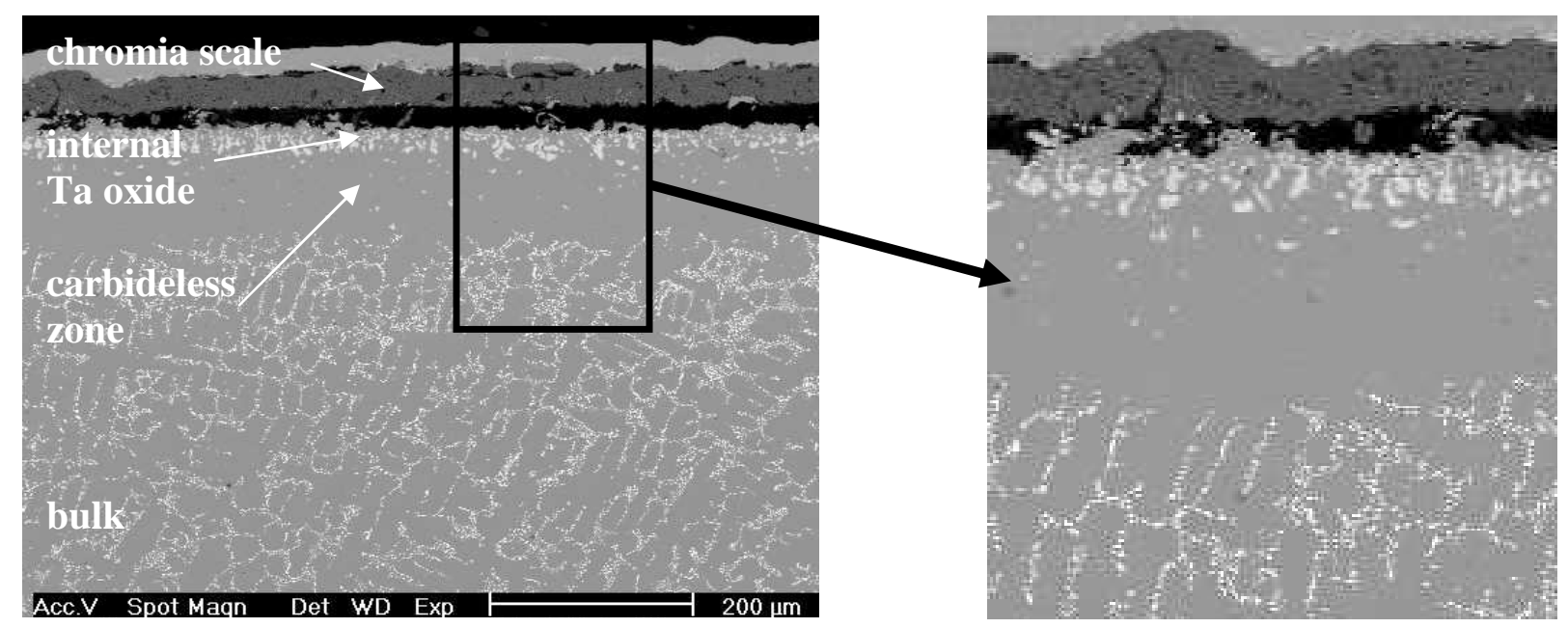

Fig. 5: Surface and sub-surface microstructural state of Alloy2 oxidised at $1200^{\circ} \mathrm{C}$ for 100 hours

Thermodynamic calculations. For Alloy2 oxidised at $1000^{\circ} \mathrm{C}$ and for the EDS results obtained, Thermo-Calc $\mathrm{N}$ indicates that the carbon weight content must be lower than $0.076 \%$ wt $\mathrm{C}$ at the extreme surface and lower than $0.050 \% \mathrm{wt} \mathrm{C}$ at the other side of the carbideless zone. These values are about ten times smaller than the initial $\mathrm{C}$ content of Alloy2. For Alloy3 at the same locations, calculations show that carbon content is smaller than $0.061 \%$ wt $\mathrm{C}$ and $0.019 \%$ wt $\mathrm{C}$ respectively, as is to say between ten and twenty times smaller than the initial $\mathrm{C}$ content of this alloy. Calculations were also performed on the compositions of the zones containing acicular carbides. For Alloy2, calculations converged to the experimental mass fractions of phases resulting from image analysis for $0.27 \%$ wt $\mathrm{C}$. The final calculation results gave $2.6 \%$ mass of $\mathrm{Cr}_{23} \mathrm{C}_{6}$ and $1.6 \%$ mass of TaC. For Alloy3, calculations allowed to come close to the real mass fractions for $0.55 \%$ wt $\mathrm{C}$. For Alloy 2 oxidised at $1200^{\circ} \mathrm{C}$, from the extreme surface towards the beginning of the bulk the maximal possible carbon content decreases from $0.23 \%$ wt $\mathrm{C}$ down to $0.08 \% \mathrm{wt} \mathrm{C}$. Like Alloy1 at $1100^{\circ} \mathrm{C}$, no zone enriched with carbon can be seen here all over the bulk. 


\section{Consequences on the thermal properties of the alloys}

In the carbideless zone and in the acicular carbides zone, the new local microstructure is due to an evolution of the chemical composition. It can induce changes for the local refractoriness of each zone in the alloy, and there is a melt hazard if working temperature suddenly raises quickly, as it can be encountered for hot industrial pieces. Using ThermoCalc on the local new chemical compositions allows to know what are locally the new solidus temperature. Table 2 displays these calculated values with two cases for the carbideless zones : carbon being equal to its lowest possible value $(0 \%)$ or to its highest one $\left(\mathrm{C}_{\max }\right)$. In fact it appears generally that these new microstructural areas are more refractory than the initial alloy, except for the acicular carbide zone (the solidus of which is sensibly equal to the bulk one).

\begin{tabular}{|c|c|c|c|c|c|c|}
\hline \multirow[t]{2}{*}{ Alloys } & \multirow[t]{2}{*}{ Locations } & external limit & middle & internal limit & \multirow{2}{*}{$\begin{array}{l}\text { acicular } \mathrm{Cr}_{7} \mathrm{C}_{3} \\
\text { carbide zone }\end{array}$} & \multirow[t]{2}{*}{ bulk } \\
\hline & & \multicolumn{3}{|c|}{ of the carbideless zone } & & \\
\hline \multirow{2}{*}{$\begin{array}{l}\text { Alloy1 } \\
1000^{\circ} \mathrm{C} \\
\end{array}$} & $\mathrm{T}_{\text {solidus }}(\mathrm{C}=0)$ & 1417 & 1 & 1406 & \multirow[t]{2}{*}{1317} & \multirow[t]{2}{*}{1317} \\
\hline & $\mathrm{T}_{\text {solidus }}\left(\mathrm{C}=\mathrm{C}_{\max }\right)$ & 1381 & 1 & 1380 & & \\
\hline \multirow{2}{*}{$\begin{array}{l}\text { Alloy1 } \\
1100^{\circ} \mathrm{C}\end{array}$} & $\mathrm{T}_{\text {solidus }}(\mathrm{C}=0)$ & 1408 & 1 & 1393 & \multirow{2}{*}{ I } & \multirow[t]{2}{*}{1317} \\
\hline & $\mathrm{T}_{\text {solidus }}\left(\mathrm{C}=\mathrm{C}_{\max }\right)$ & 1346 & 1 & 1350 & & \\
\hline \multirow{2}{*}{$\begin{array}{l}\text { Alloy2 } \\
1000^{\circ} \mathrm{C} \\
\end{array}$} & $\mathrm{T}_{\text {solidus }}(\mathrm{C}=0)$ & 1455 & 1 & 1417 & \multirow{2}{*}{$\begin{array}{c}1277 \\
/\end{array}$} & \multirow[t]{2}{*}{1281} \\
\hline & $\mathrm{T}_{\text {solidus }}\left(\mathrm{C}=\mathrm{C}_{\max }\right)$ & 1418 & 1 & 1388 & & \\
\hline \multirow{2}{*}{$\begin{array}{l}\text { Alloy2 } \\
1200^{\circ} \mathrm{C}\end{array}$} & $\mathrm{T}_{\text {solidus }}(\mathrm{C}=0)$ & 1446 & 1428 & 1392 & \multirow{2}{*}{$\begin{array}{l}1 \\
1\end{array}$} & \multirow[t]{2}{*}{1281} \\
\hline & $\mathrm{T}_{\text {solidus }}\left(\mathrm{C}=\mathrm{C}_{\max }\right)$ & 1328 & 1323 & 1345 & & \\
\hline \multirow{2}{*}{$\begin{array}{l}\text { Alloy3 } \\
1000^{\circ} \mathrm{C} \\
\end{array}$} & $\mathrm{T}_{\text {solidus }}(\mathrm{C}=0)$ & 1423 & 1 & 1393 & \multirow{2}{*}{$\begin{array}{c}1278 \\
/\end{array}$} & \multirow[t]{2}{*}{1277} \\
\hline & $\mathrm{T}_{\text {solidus }}\left(\mathrm{C}=\mathrm{C}_{\max }\right)$ & 1391 & 1 & 1382 & & \\
\hline
\end{tabular}

Table 2: Values of carbon content limits and of resulting local solidus temperatures

\section{Interpretation and discussion}

The existence of the carbideless zone is possible only if carbon quantity is smaller than very low values. There, carbon content can be considered as negligible compared to carbon contents of initial alloys and of neighbour zones containing old or new carbides. This zone has almost lost all its carbon atoms whereas the zone in which acicular carbides appeared exhibits a higher carbon content that the initial one. Since bulk presents the initial carbon content, the additional carbon necessary comes from the zone which has lost its carbides. It is possible to simplify the carbon content profile through the damaged zone (Fig. 6). Taking the example of the Alloy1 oxidised at $1000^{\circ} \mathrm{C}$, it can be considered that the carbon content is zero across the carbideless zone. It increases quickly and stays at $0.435 \%$ wt $\mathrm{C}$ across the acicular precipitation zone, and falls quickly to the bulk content $0.20 \%$ and thereafter stays at this value.

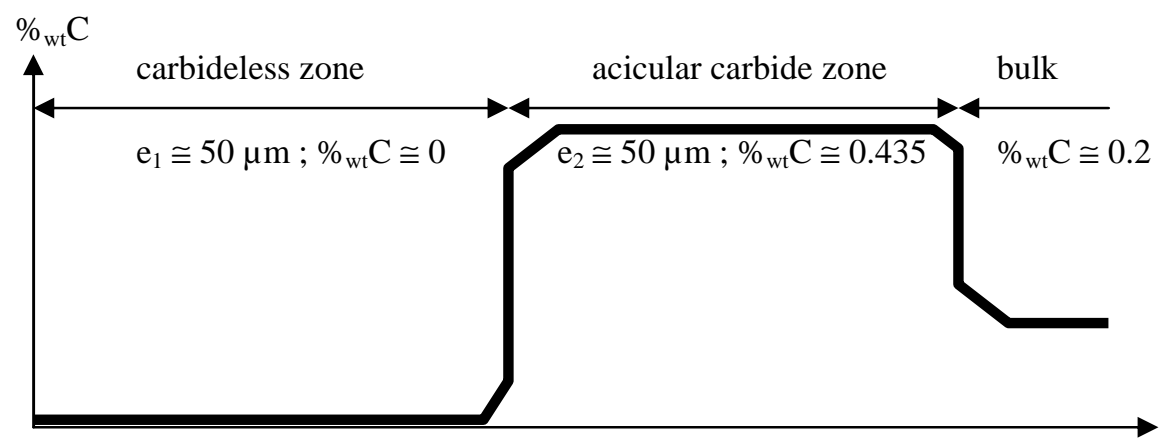

Fig. 6: Scheme of the carbon content evolution through the damaged zone of Alloy1 $\left(1000^{\circ} \mathrm{C}\right)$ 


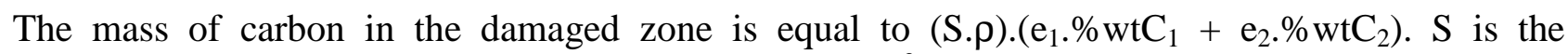
considered surface, $\rho$ is the alloy density (about $8.9 \mathrm{~g} \cdot \mathrm{cm}^{-3}$ ). $\mathrm{e}_{\mathrm{i}}$ and $\% \mathrm{wtC}$ are the depths and carbon contents of the two parts of the damaged zone. For $1 \mathrm{~cm}^{2}$ of external surface, we find about $0.30 \mathrm{mg}$ of $\mathrm{C}$ in the damaged zone, which is sensibly the initial carbon mass contained in the same volume $(0.27 \mathrm{mg})$. Then, almost all the carbon lost by the carbideless zone came into the matrix more deeper in the alloy. This carbon left the grain boundary chromium carbides, the decomposition of which was promoted by the diffusion of $\mathrm{Cr}$ towards the oxidation front. Thereafter, they diffuse backwards and entered into the matrix and met chromium atoms present in solid solution. There carbon formed with chromium new carbides which precipitated in matrix with an acicular shape. In a same grain, these new carbides exhibit a same orientation. They may coexist with the initial grain boundary carbides which have not yet disappeared and which have a more compact shape.

At $1100^{\circ} \mathrm{C}$, the mechanisms would not be the same, since no carbon enrichment can be noted elsewhere in the alloy. Carbon lost by decomposition of the initial grain boundary carbides disappears, without any doubt being oxidised into $\mathrm{CO}$ or $\mathrm{CO}_{2}$ gases. For $1 \mathrm{~cm}^{2}$ of Alloyl external surface and a carbideless zone of about $100 \mu \mathrm{m}$ in which carbon content is negligible, the same type of calculation as before leads to a carbon mass lost of $180 \mathrm{mg}$ that became gas.

Unfortunately, such calculations are not really possible for the two cobalt alloys. Indeed, zones with acicular precipitated carbides often are partially mixed in their inner part with remaining grain boundary carbides and it is difficult to be precise. But new acicular $\mathrm{Cr}_{7} \mathrm{C}_{3}$ carbides also appear among the initial $\mathrm{TaC}$ secondary carbides for Alloy2, and among the initial secondary $\mathrm{TaC}$ and $\mathrm{Cr}_{7} \mathrm{C}_{3}$ for Alloy3. For the two alloys it is a consequence of an increase of the total carbon contained in the matrix alone. This clearly shows that the mechanism of integration of carbon into matrix also acts here. Like Alloy1 at $1100^{\circ} \mathrm{C}$, it was seen for Alloy2 that a raising of the temperature unable this phenomenon which is probably also replaced by a disappearance of carbon from the alloy (becoming oxidised into gases). But this difference of behaviour remains to explain.

Finally thermodynamic modelling allowed us to verify that these new compositions induced by oxidation are not prejudicial for the alloys sub-surface refractoriness.

\section{Conclusion}

It can be underlined that thermodynamic modelling, associated to microstructure phase quantitative analysis and microanalysis, was of a good help to better characterise and understand what it happened to our specific alloys and superalloys. This method allowed to supply the lack of microanalysis techniques for what quantitative measurements of contents for light and rare elements is a real problem. With this particular procedure it became possible to localise carbon, which is an element of a great importance in our alloys. Consequently curious phenomena have been identified.

\section{References}

[1] P. Kofstad: High Temperature Corrosion (Elsevier 1988)

[2] E.F. Bradley: Superalloys : A technical guide (ASM International 1988)

[3] C.T. Sims and W.C. Hagel: The superalloys (John Wiley \& Sons 1972)

[4] Handbook of Chemistry and Physics, 57 ${ }^{\text {th }}$ edition (1976-1977)

[5] S. Michon, P. Berthod, L. Aranda, C. Rapin, R. Podor and P. Steinmetz: Calphad Vol. 27/3 (2004), p. 289

[6] P. Berthod, S. Michon, L. Aranda, S. Mathieu and J.C. Gachon: article to be published in Calphad

[7] P. Berthod, S. Michon, J. Di Martino, S. Mathieu, S. Noël, R. Podor, C. Rapin: Calphad Vol. $27 / 3$ (2004), p. 279 